\title{
MALU SENSITIVITY AND THE IDENTITIES OF NON- HETERONORMATIVE MALAY MUSLIM MEN IN PENINSULAR MALAYSIA
}

\section{Chua Hang-Kuen}

School of Distance Education, Universiti Sains Malaysia, Pulau Pinang, MALAYSIA

Email: hkchua@usm.my

Published online: 24 April 2019

To cite this article: Chua, H-K. 2019. Malu sensitivity and the identities of non-heteronormative Malay Muslim men in Peninsular Malaysia. Kajian Malaysia 37(1): 109-130. https://doi. org $/ 10.21315 / \mathrm{km} 2019.37 .1 .5$

To link to this article: https://doi.org/10.21315/km2019.37.1.5

\begin{abstract}
Apart from Islamicheteronormativity, malu (shame) sensitivity remains a significant cultural code of conduct in informing Malays' social relations and sexualities in public domains. Yet it remains obscure as how malu operates in the mundane lives and governs the identities of non-heteronormative Malay Muslim men in Malay Peninsula. The narrations examined here illuminate the social dynamics of malu sensitivity and how navigating these social dynamics inhibits and permits the expressions of non-heteronormative identities in public. It is concluded that the expressions of their non-heteronormative identities lie between conforming to and resisting the tacit Rousseauian social contract circumscribed by malu sensitivity and Islamic heteronormativity. On the one hand, they have to conform to the tacit social contract and restrain their non-heteronormativities. On the other hand, they capitalise on social tolerance and Islamic sex segregation, draw on gay liberalism discourse, and rely on tactful navigating strategies to resist the social conventions. As a result, their identities become diverse, ambiguous, fragmented and depoliticised.
\end{abstract}

Keywords: Malay, Muslim, shame culture, homosexuality, identity 


\section{INTRODUCTION}

As a male researcher recruiting non-heteronormative Malay Muslim men for interview, I pre-empted the possibility of sexual advances from potential informants; but little did I expect vulgar hostilities from my countrymen who are known to value "refined restraint" (Goddard 1997, 186). The hostilities came in the form of vulgar accusations ${ }^{1}$ of my research on non-heteronormative Malay Muslim as an attempt to memalukan (lit. to shame) the community. Before I could figure out the significance of these hostile accusations in my investigation, a more momentous incident compelled me to examine further the Malays' concern of shame and its implications on their sexualities.

On 15 December 2010, Seksualiti Merdeka, a Kuala Lumpur based Lesbian, Gay, Bisexual, Transgender and Queer (LGBTQ) advocacy group launched the second "It gets better in Malaysia" videos on YouTube. Compared to the first video featuring a local gay Chinese singer, the second video excited more Malaysians, particularly the Malay Muslim public and the ethno-religious nationalist state. Such excitement came up as, for the first time in Malaysian history, a Malay Muslim gay man, Azwan Ismail, came out in public. Azwan's coming out received overwhelming responses from Malaysian netizens and the state spokespersons. It was unsurprising that most of the responses from Malay Muslim netizens and all the responses from the state spokespersons were homophobic and hostile. Again, there were marked concerns of malu or shame in their responses. At certain point the hostility escalated into violence. Some Malay Muslim netizens were reported to have issued death threats against Azwan (The Sun Daily, 2010). Out of concern for Azwan's safety, Seksualiti Merdeka took down the video and stopped releasing the rest of the videos. The incident subsided not long after the video which perceived to bring shame was taken down.

Consistent with the trend in queer studies, Azwan's video offered Goh (2011; 2013), Kuga Thas (2013), Tan (2012), and Wong (2013) a vignette for their enquiries into the identity politics and rights of non-heteronormative people visà-vis political Islam and hegemonic heteronormativity in Malaysia. However, the aforementioned vulgarity and hostility over the visibility of non-heteronormative Malay Muslim men from a culture valuing "refined restraint" (Goddard 1997, 186) demanded for an alternative investigation of non-heteronormativities in Malay Muslim's cultural and emotional terms, i.e. Malay's malu sensitivity, an area queer theorists often ignore (Green 2002, 522-523).

Many scholars in Malay studies regard malu sensitivity as the key to understanding the Malay culture. Studies of Collins and Bahar (2000), Goddard (1996; 1997), Lee (1981), Maeda (1975), Peletz (1996), Swift (1965), and Zawawi (1998) illuminate the significance of malu sensitivity in informing and governing Malays' social relations and etiquette, including gender and sexual ones, to 
engender communal consensus and cohesion. However, none of these studies have specified how this cultural code practically creates communal consensus and its significance in the constitution of Malay social order; and how it informs and governs the social relations and identities of social deviance, sexual deviance in particular.

These research gaps are especially relevant as there is a sizeable hidden population of non-heteronormative Malay Muslim men living in Peninsular Malaysia, who, despite the spreading of global LGBTQ liberation movement, choose to be discreet. While the vulgar and hostile reactions foretell such discretion, it remains in questions as how malu sensitivity engenders such conformity in the mundane lives of these men, how they navigate this cultural terrain and how such navigations impact their identities; and how to make sense of a social order that values refined restraint but uses vulgarity and hostility in communal consensus building.

Hence, the objectives of this manuscript have two folds. On the one hand, it uses non-heteronormative sexuality as social context to investigate the operation of malu sensitivity in everyday life, and to account for the social order which the latter helps to constitute. One the other hand, it uncovers how these men exercise their sexual identities within the influence of globalised gay liberalism and limitations of malu sensitivity and Islamic heteronormativity in public Peninsular Malaysia. As such, this manuscript contributes not only to queer studies by grounding it within culture specific context; but also adds to the field of Malay studies by shedding light on the practical operation of malu sensitivity and Malay social order.

\section{MALU SENSITIVITY}

Malu is usually glossed in bilingual dictionaries as negative social emotions such as "ashamed", "shy" or "embarrassed". Although they are not inaccurate, these translations do not convey the fact that Malays also regard malu as a social good, somewhat akin to a "sense of propriety" (Goddard 1996, 432). Therefore, scholars studying Malay culture consider malu a highly productive cultural concept governing Malay social relations and etiquette, including economic and gender relations.

Although malu sensitivity is regarded as a significant cultural code in shaping the Malay society, the body of work on this subject is rather limited. Swift was among the earliest to record this "hypersensitivity" in governing social and economic exchanges in Malay peasant society $(1965,110)$. Lee $(1981,237)$ and Maeda $(1975,166)$ reported the avoidance of feeling malu as a social mechanism to instil discipline and communal consensus respectively. Zawawi (1998, 120-160) developed further the sensitivity in governing the moral of economic exchange. 
Collins and Bahar (2000, 42-49) and Peletz's (1996, 228-229) studies focused on the construction of gender difference through gendered socialisation of malu sensitivity in men and women. In addition, Collins and Bahar (2000) also elucidated Malays' psycho-social reaction to malu and its significance in Indonesia's political rhetoric debates. A more comprehensive account of malu sensitivity was Goddard's $(1996 ; 1997)$ studies of this cultural code embedded in Malay's "way of speaking".

In his study of Malay village life, Swift argues that Malays' fear for malu is a "hypersensitiveness to what other people may be thinking about one" (1965, 110). There are essentially four conditions reported by Goddard (1997, 432-434) when this "hypersensitiveness" may be invoked: (1) doing or thinking of doing something perceived to be inappropriate or foolish, (2) having a shameful personal characteristic, such as ugliness or poverty, (3) feeling malu on account of the shameful deed or character of a family member, and (4) being teased, criticised or complained about because of one's shameful deed or character. These mean the feeling of malu is pre-emptive as well as a reaction to actual situations and it can also be collectively shared. Nevertheless, malu sensitivity itself does not sanction what constitute shameful deeds or characters, the determinants are normative values and morals. As Malay adat or custom values propriety, refine restraint, cordiality and sensitivity (Goddard 1997, 186), Malays will evaluate others' deeds or characters along these rules of etiquette. Since Malayness is conflated with Islam (Lian 2001; Shamsul 2001a; 2001b), Malays also judge others following Islamic decrees.

According to Lee $(1981,237)$, the socialisation of malu sensitivity starts at home, where children are shamed by their parents in the presence of others siblings, relatives or friends - when they misbehave. Following Collins and Bahar (2000, 38) and Peletz $(1996,228)$, another socialisation method for boys is to trick them into exposing their penises and then tease/shame them for doing it. The socialisation of malu sensitivity is essentially meant to inculcate a sensitivity or "feeling of being observed or watched by others" (Maeda 1975, 166). This sensitivity that compels Malays to fit in and behave in accordance with the rest resulting in communal consensus and cohesion (Maeda 1975, 166). However, given the limited discussion in the literature available, it is not possible to ascertain how such conformity is practically achieved and maintained in the mundane life.

\section{Malu and Maruah: Two Sides of the Same Coin}

To fully understand malu sensitivity, it demands the understanding of another concept - maruah. The word maruah is variously translated into English as "dignity", "self-respect", "self-worth", "pride", and the like. However, these English concepts are egoistic and do not take into account of others' opinion upon oneself. The closest translation is perhaps the French philosopher Jean-Jacques 
Rousseau's concept of amour propre, which denotes a self-esteem that depends on the opinion of others (Vreeland 1977, quoted in Goddard 1997, 188). The sense of maruah not only regulates general social exchange but also governs the moral of economic exchange through the rights to maruah, which Zawawi (1998, 120-124) describes as Malay "proletarian moral economy" [see further in Scott's (1976) moral economy of the peasant]. Given Malays' concern over one's social (and economic) standing in the eyes of others, maruah therefore bears a clear connection to malu as the other side of the same coin.

There are also other malu-maruah related Malay words - bangga (lit. proud) and sombong (lit. arrogant). Bangga is the converse of malu. The feeling of bangga is triggered in the opposite ways of malu, such as when one is perceived to be doing well or having admirable characteristics (Goddard 1996, 436). However, if one took pride in an undesirable quality, then he will be regarded as sombong or having arrogant pride (Goddard 1996, 437).

\section{Reactions to Feeling Malu or Loss of Maruah}

According to Goddard (1997, 188), feeling malu implies a loss of maruah; conversely, maintaining one's maruah involves pre-empting any unpleasant sense of malu. Hence Vreeland (1977, quoted in Goddard 1997, 187) argues that Malay people treasure their maruah and will defend it jealously. When their maruah is challenged, Malays may resort to accommodation, withdrawal or resistance (Zawawi 1998, 149-156). Should the feeling of malu or loss of maruah become too overwhelming, some people may resort to culture- and gender-specific syndromes of amuk for men and latah for women (Collins and Bahar 2000, 50-54) [see Winzler (1990) and Kenny (1990) for other psycho-social causes of amuk and latah; also Lee (1981) who proposes the dyad as anti-structural behaviours]. Amuk is expressed in the form of aggression, madness or even violent attack which may result in death. Latah is a compulsive expression of, ironically, obscene or embarrassing words or behaviours (Collins and Bahar 2000). Nevertheless, these intense malu reactions seldom occur because while Malays tend to avoid being shamed, there are also other reciprocal moral regulators called timbang rasa (lit. to empathise) (Zawawi 1998, 138) and tolerance (bertolak ansur in Malay) (Maeda $1975,166)$ that regulate one's moral power to shame or to lower other's dignity.

As such, in the construct of malu sensitivity, all social behaviours are regulated in such a way as to avoid being shamed or preserve one's own maruah, and to avoid invoking the feeling of malu or to safeguard the maruah in others. It is through malu sensitivity that social disruption is avoided (Goddard 1997, 188). 


\section{Malu Sensitivity as Rousseauian Social Contract}

From the preceding discussion it can be inferred that the Malay social order circumscribed by malu sensitivity coincides with Jean-Jacques Rousseau's social contract, which can be summed up in his most well-known statement:

[social contract is] a form of association that will defend and protect the person and goods of each associate with the full common force [or general will], and by means of which each, uniting with all, nevertheless obeys only himself and remains as free as before (1997, 49-50).

In this light, the Malay customary expectation to be proper, refined, courteous and, most importantly, to know malu forms the basis of the "general will" (Rousseau 1997, 49-50). Within this construct, an individual's amour propre and interests, so as the common good, are protected and defended through the observation of malu sensitivity; and by means of which communal consensus and cohesion are sustained.

The most distinctive feature of Rousseauian social contract lies in the seemingly paradoxical second part of the statement. What Rousseau means by obeying oneself and remains free within the social contract is by "... the total alienation of each associate with all of his rights to the whole community ... since each gives himself entirely, the condition is equal for all, and ... no one has any interest in making it burdensome to the rest" (Rousseau 1997, 50). Following Rousseau idea, when individual Malay alienates or submit his individuality and personal will to observe the malu sensitivity, he will be freed from feeling or being shamed.

In the context of this manuscript, what will happen should one choose not to submit his non-heteronormativity or to deviate from the collective sexual norm?

\section{Malu Sensitivity and Its Implications for Sexual Deviance}

First, there are no specific words for "sex" or "genitals" in the Malay language (Shamsul and Mohamad 2006, 64). The Malay word for sex is "seks", which is an English transliteration. Meanwhile "zakar" (penis) and "faraj" (vagina) are Arabic loan words (Shamsul and Mohamad 2006, 64). The only proper Malay term for genitals is kemaluan (lit. something to be ashamed of, like "private parts" in English), which is a euphemism based on the root word malu (Peletz 1996, 228; Shamsul and Mohamad 2006, 64). The use of such a euphemism reflects Malays' refined restraint or malu feeling towards sexuality, especially in public (Shamsul and Mohamad 2006, 64). 
Given such strong association between malu and sexuality, Collins and Bahar note "sexually provocative behaviour by self or others should elicit malu" $(2000,42)$. This means any form of sexual deviances is considered shameful and should trigger malu related reactions. Hence Boellstorff $(2007,171-174)$ refers to Collins and Bahar's (2000) malu-related amuk to explain a violent attack of 350 non-heteronormative delegates by 150 youths during a public event in Central Java in 2000. According to Boellstorff, such violence is a malu reaction to the perception that a "particular kind of nationalised masculinity is at stake" due to the public representation of non-heteronormative men $(2007,174)$. Similar explanation may be applied to the death threats against Azwan's coming out, because Malaysia also promotes similar nationalised masculinity through the criminalisation of homosexuality by civil law (i.e. Penal Code 377) and Islamic law (see further in Goh 2013).

These violent reactions to sexual deviance also correspond with Rousseauian social contact: “... whoever refuses to obey the general will shall be constrained to do so by the entire body: which means nothing other than that he shall be forced to be free" (Rousseau 1997, 53). What Rousseau means by "forced to be free" is really "compelled to obey" (Dagger 1981, 363). In this light, the aforementioned vulgarity, hostility, amuk and latah can be understood as radical rectifications to the breaching of the social contract when individuals failed to protect the maruah of the collective and vice versa. Nevertheless, how this intrinsic social contract operates in and impacts the lives of non-heteronormative Malay Muslim men remain understudied.

\section{RESEARCH METHOD}

This investigation used a semi-structured in-depth interview approach (Minichiello et al. 1995) to collect empirical information from 34 non-heteronormative Malay Muslim men. These men were recruited from Kuala Lumpur, Johor Bahru and Kota Bharu through two gay dating websites. ${ }^{3}$ The interviews with them took place between March 2010 and January 2011. Thematic analysis (Braun and Clarke 2006) was used to analyse the interview transcripts which are mostly in Malay. All quotations presented in this manuscript have been translated/edited to make them reader friendly while preserving the original tone and cultural references.

Ethical clearance for this study was granted by the La Trobe University Human Ethics Committee prior to the commencement of informant recruitment and interviews. All of them had given their written consents to be interviewed and to allow their stories to be published anonymously. Therefore, all the names stated are pseudonyms. 


\section{THE INFORMANTS}

All informants identified themselves as Malay Muslim men. They were between the ages of 18 to 59 years during the interviews. They came from all walks of life - from successful businessman with doctoral degree to general worker with secondary education. They also reported having diverse sexual orientations and identifications. Some reported being exclusive homosexuals, while others being bisexuals with varying preferences between the sexes. Some were single, living with their male partners, dating men and/or women, and a few were married with children. Some of them identified as gay, $\mathrm{PLU}^{4}$ or bisexual; and some avoided any identity labels. Therefore, I use "non-heteronormative" instead of "homosexual" or "gay" when referring to this group of men.

Only a handful of them disclosed their sexualities to other straight people or families; the majority of them kept their sexual identities hidden. Even among those who did disclose their non-heteronormativities, none of them had gone as far as Azwan. These limited self-disclosures indicate there had been attempts to regulate and navigate their identities in public.

Based on the scholarly treatises, the investigation of how malu sensitivity operates in the context of non-heteronormative Malay Muslim men's lives begins with inspecting (1) the aspects of their non-heteronormativities that are capable of invoking the feeling of malu in them and the social groups they belong to, (2) the dynamics of social control and social tolerance of their non-heteronormativities, and (3) how these men navigate the malu sensitivity before conclusions are drawn.

\section{THE MALU OF NON-HETERONORMATIVE MALAY MUSLIM MEN}

\section{Personal Malu}

Consistent with Malays' euphemistic attitude towards sexuality in the literature, most of these men associate malu with genitalia and sexuality. They consider public display of their penises and sex acts inappropriate and shamable, even in gay saunas! Adam (46 years old), a married bisexual gay sauna worker explained: "Some of them really feel malu to bare themselves, they will cover themselves with towels ... but some just strip off. They don't care; they just do it (have sex) in front of others! That's too much! For Adam, Adam feels malu." Two men had experienced the shame of such public exposure: Irwan's (23, creative entrepreneur) naked pictures with his male lover were leaked and circulated online; and Aidil (32, salesman) was implicated when naked pictures of his religious teacher sent to him were discovered by the school administration. As a result, Irwan socially isolated himself for two years to avoid the embarrassment; and Aidil was constantly shamed 
after the incident. It is clear that the matters causing malu must either be visible or known to others. Therefore, they will not risk feeling malu if they conceal their private parts and sex acts.

Although similar discretion is also applicable for heteronormative people, non-heteronormative people face another risk of malu. As homosexuality is censured by Islamic heteronormativity, these men are generally feeling guilty and malu for having such deviant sexualities.

Unlike genitalia and sexual orientation that can be concealed from others, effeminacy and gender-crossing are visible characteristics that are harder to hide. Since these traits are visible, effeminate men usually learned about effeminacy and malu from a very young age. Lamentably, they often learned from being ridiculed by their peers or even teachers. However, some embrace their effeminacy and they did not talk about feeling malu for their effeminacy. But it does not mean they are free from feeling malu; rather, their effeminacy is tolerated. I shall return to this social tolerance later.

\section{Communal Malu}

It is worth noting that the malu of non-heteronormativities can be implicating especially when it becomes visible. Therefore, most men avoid socialising with visible effeminate men, pondan (transgender) or mak nyah (transsexual) in public lest they became "malu by association". While these men are aware that they can be implicated by others, they are also aware about the reverse. Hence some of these men show substantial concern over the malu/maruah of their family, the Malay Muslim community, formal organisations and even the nation.

\section{The Family's Malu}

Similar matters are also perceived to conjure up malu feelings in their family members. This could be traced from their families' responses when the families found out about them. Among them, Irwan and Harris (35, manager) had experienced their families' malu-related reactions when their homosexuality was exposed. Prior to the leak of Irwan's nude pictures, his same-sex relationship with his abang angkat ${ }^{5}$ (chosen older brother) was discovered by his mother. Irwan's parents became so furious that they threw the then 14-year-old out of the house! Even though he did not associate his parents' reaction with amuk or latah, his parents must have been so ashamed and enraged to disown a dependent child. ${ }^{6}$ In Harris' case, his mother reacted in a milder amuk behaviour known as "mengamuk" (raging or ranting) after she became suspicious of Harris and his mate's relationship during a family trip. Harris recounted: 
We were returning to Malaysia. She exploded like crazy at him ... She mengamuk [sic] in the boarding hall. She kept scolding me until we went inside the cabin. ... [then] she shouted at my boyfriend in the aisle, "I am disgusted to see your face!" What an embarrassment!

In some cases, individuals' traits not only concerned the family, but also the extended families. This is particularly true for prestigious families like Syed's (37, manager). The Syeds are reportedly linked to the Prophet Muhammad and hence are considered one of the prestige families in the Muslim world (Kazuhiro 2012). Given this significance, he is very concerned about the reputation of the Syeds; likewise, the Syeds also guard their reputation jealously, he explained, "When I meet someone, the next day my relative will ask me, 'Who were you meeting last night?",

\section{The Malu of Organisations and Beyond}

Similar communal malu sensitivity is also applicable to organisations. Some of them were very cautious about the reputations of their alma maters and employers during the interviews that they asked to omit the name of these organisations, especially when they have strong links to the state. Faizal (26, manager) had previously worked for one of the Malaysian ministries before moving to one of the government-linked companies. Despite acknowledging that homosexuality does not compromise one's professional capability, he left the ministry out of concern for its public image and the perceived homophobic environment. At the time of the interview, Faizal was managing a project dealing with foreign investors; alongside this role, Faizal's concern about public image was extended from the company to that of the country. He said, "Sometimes my colleagues and I will talk about homosexuality ... we blame the gay men because they bring bad image to the country."

Along similar lines, after Azwan's incident, I asked the last nine men I interviewed for their comments. Most of them thought his coming out could compromise the collective maruah of Malay Muslims. Tengku (28, waiter) commented, "You see, when you're a Malay and you declare you like men, you will damage the maruah of Malay people. They will condemn you." This explains the vulgar messages I received and the hostilities from the Malay Muslim netizens and ethno-religious nationalist state against Azwan. Although the vulgar and violent reactions contradict the customary expectations of refined restraint and proper behaviours, they do not seem to result in malu itself. As alluded in the Rousseauian social contract, the necessity to enforce conformity in those who have deviated from the general will seems to justify such vulgarity and violence. Nevertheless, similar contradiction is also found between social control and tolerance of nonheteronormativities within the construct of malu sensitivity. 


\section{THE DYNAMICS OF SOCIAL CONTROL AND SOCIAL TOLERANCE OF NON-HETERONORMATIVITIES}

All of them experienced or anticipated informal and formal social control to enforce their conformity to heteronormative norm. As noted by Maeda $(1975,166)$, the anticipation is a constant feeling of being watched by sanctioning eyes of others which forms the basis of social conformity. Expectedly these actual and perceived social controls are initiated by people or groups whose maruah can be affected by their non-heteronormativities.

\section{Family Interventions}

As family's maruah is hinged upon the behaviours of its members, it becomes the affair of the family, particularly the parents, to continually watch out and intervene in their children's deeds and characters. Preventive measures may be taken if the family becomes suspicious about their non-heteronormativities. Since the basic learning of malu sensitivity is through making one feel malu (Lee 1981), it often translates into the elders in the family making them feel malu for behaving inappropriately. Haqim's (18, student) older brother suspected his homosexuality when the brother spied on his mobile. Instead of reproaching, he ridiculed Haqim continuously. According to Haqim, his brother was trying to make him feel malu so that he might quit.

Another approach is aimed at monitoring and correcting these men's known or suspected non-heteronormativities. For instance, Iman's (26, postgraduate student) family monitored his behaviour closely while he was away from home:

I never wore jeans prior to 2007. My family noticed that and they passed a cynical comment, "Oh, you're wearing jeans; we thought ustaz [Islamic scholar] never wears jeans." During that time I was also wrestling with my sexuality and it affected my study. Then my uncle and my brother came to Kuala Lumpur to interrogate me. They asked me so many questions ... [including] "Do you have any feeling towards guys?"

Some parental interventions may come across as coercion, i.e. Harris' mother's milder amuk reaction in the cabin and Irwan's parents throwing him out of the house.

\section{Whistle-Blowers, Busybodies and Gossipers: Informal Social Control}

According to Maeda (1975, 166), Malays avoid confronting others' wrong doings whenever possible as an observation of the customary empathy, tolerance and refined restraint. This may pose a challenge for the community to impose 
discipline and enforce conformity if they have no parental authority or do not resort to coercion above. In the stories of the men interviewed, there were recurring narrations of annoying and imposing characters who pried into and spread news/ gossips about others' privacies. It is evident that the Malay community uses these non-confrontational and passive aggressive approaches - prying, taletelling and gossiping to impose, at least at face value, conformity. After all malu sensitivity is about the opinions of others about one. These bothersome characters are predominantly neighbours, friends, relatives and co-workers. Although they include LGBTQ people, I shall focus only on the former, because they constitute the main informal social control "taskforce".

Most men are anxious about and annoyed with the whistle-blowers. Whistle-blowers are familiar people who will report to their families if they found out about their "abnormality". Apart from relatives, neighbours are among the nosiest people in these men's stories. In addition to snitching, they may also spread news among local communities. To depict the nosiest things neighbours are capable of doing, Jozain (34, salesperson) shared the story of a fellow villager nicknamed monggeng (Kelantanese dialect for "buttock"). The man got this disgraceful nickname because he practised anal sex with his wife; and all it took was for the wife to confide in one of their neighbours for the entire village to know. After divorcing his wife, the man was suspected to be a homosexual when he was murdered by some youngsters he allegedly picked up. Again, the speculation spread like wildfire in the village.

Similar inquisitive behaviours can also be found in the workplace. Omar (50, service provider) shared his frustration towards his nosy Malay colleagues who liked to pry into his marital status, hence he concluded, "Malays are very nosy." It is through these informal social controls that the sensitivity of being watched and judged by others are sustained and reinforced.

\section{State and Organisational Formal Interventions}

Though civil and Islamic laws in Malaysia impose corporal punishment for men found guilty of "carnal intercourse against the order of nature", the majority of them did not seem to be particularly threatened by it. This can be understood from two perspectives: First, the practicality of law enforcement; second, the penalties are perceived to be less threatening than malu.

Adam was the only man who had been implicated in a sodomy allegation under civil law. Adam's admirer made a police report against Adam for sodomising him, which was to avenge Adam's rejection of his romantic pursuit. However, the police never investigated the allegation, which in Adam's opinion, was because there were more urgent cases for them to attend to. Compared to the police force, the Islamic authority is commonly regarded as more responsive to sexual 
misconducts. However, compared to heterosexual couples, it is very difficult to prosecute and convict homosexual couples under the Islamic laws. This is because it is not an offense for two men to stay in the same room; and it is difficult to prove the occurrence of sex unless the couples are caught in flagrante or photos/videos of their sex acts are found.

Even if they are concerned about the state's prosecution, they are not as concerned about the penalties. This is not because the punishments are not severe; ${ }^{7}$ but these men consider the subsequent social shaming more frightening. Similarly, within formal organisations such as schools, the malu feeling is deemed to be more potent than the formal intervention. In Aidil's scandal with his religious teacher, he was suspended from school for two weeks; but he and his family had to put up with the shame for longer.

\section{Social Tolerance and the Threshold of Malu Sensitivity}

The discussion thus far seems to portray the Malay Muslim community as being obsessed with prying and meddling in others' gender/sexual "misfit" or "misconduct" to engender and perpetuate social conformity through malu sensitivity. However, there were also incidents reported by some men where they were not made to feel malu or required to conform to Islamic heteronormativity.

\section{Tolerance of Non-Heteronormativities}

Malay society does tolerate effeminacy and gender-crossing (Peletz 2009; Raybeck 1986; Wazir 1992). Based on Wan's (25, postgraduate student) previous gender-crossing experiences, he only encountered occasional verbal assault from passersby when he loitered with his transgender friends on the streets. In the case of Irfan, even the elders in the village endear him and his friends as "mat lembut" or gentle guys. For Mikhail (26, hairdresser), despite his unconventional fashion sense for Malay Muslim men, i.e. earring and big handbag, he has never been told off when hanging out with his fashionable PLU friends in Kota Bharu, which is known as the Islamic City!

Moreover, there are also incidents where the families of a few men accepted their sexual identities and their male partners. The families of Irwan and Thaqif (55, manager), for instance, accepted their male partners as part of the families; also Zachary and Faizal's parents had accepted their homosexuality. However, their families were acquiescent to it without making it verbal, which is in consistent with the Malays' euphemistic attitude towards sexuality.

Despite the considerably high level of tolerance of non-heteronormative men within Malay Muslim society, reflecting on Azwan's incident and the social 
controls discussed earlier, there also seems to be a limit to the tolerance towards non-heteronormativities. What then is the threshold of this tolerance?

\section{The Threshold of Tolerance}

This threshold lies within one of the basic principles of malu sensitivity - visibility. This visibility is not just about being seen or known, but to be seen as defiant and confrontational. Some of them expressed this threshold as "over", which means "overdoing it". This is stated clearly in Iman's irritation towards defiant gay men:

For me, gay men are normal guys; but sometimes they overdo it. They behave in campy, dramatic and pretentious manners, which I think is unnecessary... We do tolerate people who are different; but don't overdo it, it's like wanting everybody to know you are like that.

Men with visible effeminacy or gender-crossing are tolerated because they do not overdo it. For example, Wan, his previous gender-crossing behaviours were tolerated because he was not "over" - he only put on light makeup, wore women's T-shirt and a tracksuit bottom; but was never in drag.

The reception of others, especially family, towards their nonheteronormativities also varied according to the circumstances when these men's sexualities were found out. If they were found out in "less honourable" ways, the reactions from their families or local communities were more negative. Irwan was thrown out of the house after his mother witnessed the couple kissing in bed. Likewise, Aidil's scandal with his teacher became a communal focus because there was vulgar evidence - photos of his teacher in the nude. For those who came out or were found out in less confrontational ways, their families were generally more receptive of the news.

From the cases above, another plausible explanation for the hostility towards Azwan's coming out is that his declaration not only put the Malay Muslims' maruah at risk, but he was seen risking it intentionally in an international platform!

\section{NAVIGATING MALU SENSITIVITY}

\section{The Principles of Tactful Maruah Preservation in Public Domains}

There is a recurring phase in their stories - "pandai membawa diri", which literally means "being tactful in carrying oneself". What this means is presenting oneself in an acceptable manner in the eyes of others. In other words, one must preserve his maruah by observing malu sensitivity in public. 
There are two principles guiding their maruah preservation. The first principle, as alluded to in the previous section, is to restrain their nonheteronormativities. This is done not only to avoid feeling malu, but also not to evoke the malu sensitivity in other people, to quote Shah's (29, public servant) comment:

Living in a society, we need to consider how others may feel. So, we have to cover [sic] [our identity] in front of some people. However, sometimes we also have to be who we are, not pretend to be someone else... I remember reading a book, it says something like we have to feel proud with ourselves; and we have to accept the way we are, then only we can live happily. So, I accepted myself, whether you like it or not.

However, in the second half of Shah's comment above, Shah proposed an idea of self-pride and self-acceptance independent of others' approval. This second principle contradicts the first. The second principle is not native to Malay or Asian culture; but the western individualism upon which LGBTQ liberalism emerges (Chou 2001, 32). Though, Zawawi (1998, 152-156) notes Malays do defy in defence of their maruah; however, such resistance is against the exploitation of capitalism, and not against the social pressure to conform.

Many men straddle the two contradicting principles as the basis of their maruah preservation. This straddling is best captured in the modifier of "pandai" or being tactful. In their contexts, being tactful means being proficient in regulating their appearance and/or behaviour to conceal or reclaim their sexualities without evoking malu sensitivity in themselves or others.

\section{Concealing and Reclaiming Non-Heteronormative Identities in Public Domains}

In order to preserve their maruah in public, they have to regulate what are perceived to be detectable by sanctioning eyes/ears while asserting their identities without exceeding the threshold of tolerance. Therefore, their expressions of identities are not bold and confrontational, yet can still be picked up by other non-heteronormative men and those who are sensitised to them. The aspects that are highly regulated included their attire, behaviour, relationship status, social networks and identity labels.

\section{Dress as Code and Camouflage}

Being fashionable is often considered the hallmark of being LGBTQ for these urbanites. Some of them reclaim their gay identity by wearing trendy men's 
fashion and accessories. However, given the increased visibility of metrosexuals in the country, fashion is no longer an exclusive identity marker for them.

Some men create an ambiguous fashion self-representation, which simultaneously helps them conceal and reclaim their identities. This is best exemplified in the case of Farish (36, consultant). His trick is to add some subtle touch such as, stylish haircut, sunglasses and necklace (which is an uncommon fashion item for Malay Muslim men) to his otherwise normative appearance. What he tries to achieve is, "Instead of letting people know straightaway from my attire, I make people guess 'Is he a PLU or not?"”

For others, in order to avoid being suspected as non-heteronormative men, some men camouflage themselves in typical menswear. Mohamed (29, businessman), for example, who presented himself differently in his dating profile and during the interview - bright and fashionable vs. dull and conventional. Yan (35, public servant), who sounds like a woman over the phone, too, appeared in conventional clothes like Mohamed during the interview - untucked plain shirt, dark trousers and dark sandals. Yan's contradicting self-presentation suggests a premeditated attempt to neutralise his effeminacy.

Another way to conceal one's non-heteronormativities is perhaps by accentuating one's "normativity". In Tengku's case, he attempts to appear like a pious Muslim by putting on celak (black eyeliner) on Friday like the Prophet. Ironically, some of his friends mistook his religious practice for black metal cult fashion, which is labelled as anti-Islamic cult (Liew and Fu 2006).

\section{Regulating Gendered Behaviour and Intimate Relationships}

Since effeminacy is commonly associated with homosexuality, most of the effeminate men regulate the way they walk and interact with others to conceal their non-heteronormativities. These regulations were observable during the interviews with a few men like Tengku, Yan and Wan, whose tones and gestures shifted from more reserved to more effeminate as the interview rapport strengthened.

Intimate behaviours wise, all of the male-partnered men consciously avoid public display of affection. It is worth noting, the sex segregation imposed by Islam and the Malay culture of chosen siblingship (see further in Wazir 1992, 188-191) do facilitate the tacit reclamation of same-sex relationship in public. The positive effect of sex segregation on their non-heteronormativities is selfexplanatory. While the positive effect of the latter is not only about disguising their same-sex relationships, it offers an opportunity to integrate their male partners into their families. For examples, before Irwan's relationship with his abang angkat was discovered, they could take part in Irwan's family functions together and even share a room in Irwan's parents' house. In Shah's case, his mother even adopts his abang angkat as anak angkat (chosen child) and treats him as part of the family. 
Since nikah (marriage) is considered the only legitimate way to express one's sexuality in Islam (Bouhdiba 1974, 30), the best way to conceal one's nonheteronormativity is to pass as a heteronormative man through having a relationship with a woman. Irfan confessed his previous attempt, "I once got engaged with a woman. However, after we had been engaged for a year, I decided not to be a hypocrite ... I didn't want to pretend I am a normal man and blind the entire society. So, I called off our engagement."

Even though marriage is not intended solely as a cover-up, these men are pressured to adhere to Islamic heteronormativity as part of the general will. Zack (40, manager), one of the married men, defended himself, "I know some people criticise married men like me ... Of course, some people get married because they want to cover up. But the reality is, living in a Malay majority society, you have to get married."

\section{Regulating Social Networks}

As mentioned previously, most of these men avoid befriending or being seen with effeminate men, pondan and mak nyah in public. For some, the best way to enjoy the company of other non-heteronormative men without raising some eyebrows is to befriend those who appear masculine or share similar reputation risk. The most common way is to confine such socialisation to the virtual world or in private spaces.

For men who befriend the mak nyah, they confine their interactions with them to private spaces i.e., their beauty salons or boutiques to sustain their friendship. Some of them take advantage of more inclusive public places like franchised restaurants and cafes. These cosmopolitan consumer venues often offer relative high degree of acceptance towards diversity. Also, as long as their behaviour do not disrupt the business, the owners will leave them alone. As Irfan explained, "the places we go, the owners and clients are well acquainted with the way we are. They are open-minded."

Some men also find their niches in certain industries. From their stories, the beauty, service, retail and creative industries are highly receptive towards LGBTQ. According to Zikri (44, wedding planner) and Mikhail, there has been a long history of male bridal makeup artists or pak andam and they remain popular among brides for their alleged acute aesthetic sensitivity. In some creative industries gay men may even become dominant players to the extent that straight players have to be receptive towards them to survive. To illustrate this, Irwan gave an example of how his straight colleague landed on a better job after dropping his homophobic attitude. 


\section{Labelling Matters}

In their maruah preservation, not only are they concerned about what others see, they also regulate what others hear. As most interviews were conducted in cafés or restaurants, such regulations were evident when they adjusted their tones and wordings when talking about their sexualities. As one will expect, the most significant aspect of their regulations is the use of the identity labels. Most of them, including those who embrace their homosexuality, use "gay" thoughtfully. For them, the term is revealing and defiant, which contradicts the first principle of maruah preservation. Therefore, even self-identified gay man like Daniel (32, teacher) truncated the word to "G" during the interview. Likewise, the word "bisexual" was truncated as "bi" (pronounced "by" or "bee"). In comparison, they are more comfortable using the label "PLU", because the term is ambiguous and not commonly known to the public; even some men find it too ambiguous as it does not denote anything sexual. As such it allows identity reclamation without upsetting the social contract.

Some men avoid using these identity labels all together. However, malu aside, such avoidance should be understood in labelling theory term as an avoidance to commit themselves to deviant sexualities. This is because they still hope to change their sexual orientations and return to the normative fold. Meanwhile, when social situations call for it, they just have to pass as heterosexuals by saying what is deemed appropriate. Khalish (37, lecturer) shared, "Sometimes when my friends talk about sex with women, I will also chime in. Sometimes I just pretend and say, 'Wow! This girl is hot!' So they will not think that I am different." They need to fit in and to appear the same as everyone else sums up the consensus building of malu sensitivity.

From the above, these men's strategies to regulate the visible and detectable aspects of their non-heteronormativities do facilitate their maruah preservation in public. However, to be tactful in maruah preservation is not just about remaining invisible in public all the time. Most of them do attempt to reclaim their non-heteronormativities in public without breaching the tacit Rousseauian social contract. However, what is lacking in their identity reclamations in public is the identity politics based on LGBTQ liberalism or human rights. As demonstrated in Azwan's public declaration, such identity politics is obviously not well received as it upsets the social contract. In addition, to take pride in a "shameful" trait will be considered as sombong or being arrogant (Goddard 1996, 437). This explains why some men may be warm towards LGBTQ liberalism but will not take pride in their non-heteronormativities in public. 


\section{CONCLUSION}

Based on the empirical information and discussions presented above, apart from some influences of LGBTQ liberalism, the tacit Rousseauian social contract circumscribed by malu sensitivity and Islamic heteronormativity remains the main social order outlining the expressions of these men's non-heteronormative identities in public.

These men are highly sensitised to malu sensitivity as how their nonheteronormativities should or should not be expressed in public. For them, any untactful expressions of their non-heteronormativities will evoke malu in them and implicate the social groups they belong vis-à-vis the dynamic and dualistic others. Many of them also experience or anticipate surveillance and interventions from these social groups and the ethno-religious nationalist state. Based on their experiences, the main purpose of these interventions is not to punish them, but to perpetuate the Rousseauian social contract. Individuals will be forced to conform if they are perceived to be breaching the social contract.

Within the social contract, "other people" who are sensitised to malu can empathise with these men's malu feeling and tolerate their differences. In turn, these men reciprocate by not confronting others through their tactful maruah preservation. By taking advantage of this social tolerance, Islamic sex segregation and chosen siblingship, many of them are able to reclaim the public spaces and to integrate their sexual selves into the heteronormative world. Hence their seemingly absent presence in public.

It can be concluded that it is not impossible for non-heteronormative Malay Muslim men to express themselves in public. However, such expressions lie between conforming to and resisting the social contract circumscribed by malu sensitivity and Islamic heteronormativity. On the one hand, they have to conform to the social contract and restrain their non-heteronormativities. On the other hand, they capitalise on social tolerance, Islamic sex segregation and chosen siblingship, draw on gay liberalism discourse, and rely on tactful maruah preservation to resist the social conventions. As a result, their identities become diverse, ambiguous, fragmented and depoliticised. In order to reclaim greater public spaces, they have to find alternative identity politics to those of "coming out" that can transcend or counter malu sensitivity and the Rousseauian social contract.

\section{ACKNOWLEDGEMENTS}

This research was supported by the La Trobe University Full Fee Research Scholarship and Postgraduate Research Scholarship. In developing the ideas presented here, I have received helpful supervision from Professor Dr Jeffrey 
Grierson and Dr Stephen McNally. I gratefully acknowledge the support and generosity of the 34 men I interviewed, without them the present study could not have been possible.

\section{NOTES}

1. These vulgar messages were sent to me via my recruitment mobile phone number and email. The independent reviewers appointed by Kajian Malaysia advised against quoting these vulgar swear words and the use of crass [sic] sexual references to accommodate its readers' sensitivity.

2. Goddard $(1997,187)$ warns readers off Swift's (1965) ethnocentric perspective when he uses the prefix "hyper-".

3. Gay dating smartphone applications were not used because they were not as popular back in 2010.

4. This is an abbreviation for "People Like Us". The abbreviation originated from the gay rights movement in Singapore in 1993 (Offord 2003).

5. While the non-consanguineal siblings usually provide each other emotional and practical supports; they sometimes also form romantic/sexual relationship with their same-sex or opposite-sex chosen sibling (Wazir 1992, 188-191).

6. Irwan stayed with his abang angkat until his parents took him back a year later and accepted their relationship.

7. Section 377B of the Malaysian Penal Code provides that oral and anal sex between consenting adults are punishable by imprisonment for a term extendable to 20 years and whipping. The punishments provided in the Sharia law vary from state to state; generally, involve a fine up to RM5,000, imprisonment up to three years, whipping up to six lashes and/or a combination of two or more.

\section{REFERENCES}

Boellstorff, T. 2007. A coincidence of desires. London: Duke University Press. https://doi. org/10.1215/9780822389538

Bouhdiba, A. 1974. Sexuality in Islam, translated from the French by A. Sheridan. London: Routledge.

Braun, V. and V. Clarke. 2006. Using thematic analysis in psychology. Qualitative Research in Psychology 3(2): 77-101. https://doi.org/10.1191/1478088706qp063oa

Chou, W.S. 2001. Homosexuality and the cultural politics of Tongzhi in Chinese society. Journal of Homosexuality 40(3-4): 27-46.

Collins, E.F. and E. Bahar. 2000. To know shame: Malu and its uses in Malay societies. Crossroads: An Interdisciplinary Journal of Southeast Asian Studies 14(1): 3569. 
Dagger, R. 1981. Understanding the general will. Western Political Quarterly 34(3): 35971. https://doi.org/10.1177/106591298103400304

Goddard, C. 1997. Cultural values and “cultural scripts" of Malay (Bahasa Melayu). Journal of Pragmatics 27(2): 183-201. https://doi.org/10.1016/S0378-2166(96)00032-X 1996. The "social emotions" of Malay (Bahasa Melayu). Ethos 24(3): 426-464. https://doi.org/10.1525/eth.1996.24.3.02a00020

Goh, J.N. 2013. Malaysian masculine exposé: Queering the politics of non-heteronormative Malay-Muslim men. In Queer sexualities: Diversifying queer, queering diversity, eds. V. Fraser, 15-30. Oxford: Inter-Disciplinary Press.

2011. Balanced genitals: YouTube confessional disclosures and signposts for Malaysian gay theologies. Theology \& Sexuality 17(3): 279-295. https://doi. org/10.1179/tas.17.3.y521585055787g78

Green, A.I. 2002. Gay but not queer: Toward a post-queer study of sexuality. Theory and Society 31: 521-545. https://doi.org/10.1023/A:1020976902569

Kazuhiro, A. 2012. The Sayyids as commodities: The Islamic periodical alKisah and the Sayyid community in Indonesia. In Sayyids and Shrifs in Muslim societies: The living links to the Prophet, eds. M. Kazuo, 247-266. London: Routledge.

Kenny, M.G. 1990. Latah: The logic of fear. In Emotions of culture: A Malay perspective, eds. Wazir J.K., 123-141. Singapore: Oxford University Press.

Kuga Thas, A.M. 2013. No right to live? Malaysia's Islam and implications for its sexual minority storytellers. Paper presented at the 4th Global Conference on Storytelling: Global Reflections on the Narrative in Prague, Czech Republic. 21-24 May.

Lee, R.L.M. 1981. Structure and anti-structure in the culture-bound syndromes: The Malay case. Culture, Medicine and Psychiatry 5(3): 233-248. https://doi.org/10.1007/ BF00050770

Lian, K.F. 2001. The construction of Malay identity across nations Malaysia, Singapore, and Indonesia. Bijdragen tot de Taal-, Land-en Volkenkunde 157(4): 861-879. https://doi.org/10.1163/22134379-90003795

Liew, K.K. and K. Fu. 2006. Conjuring the tropical spectres: Heavy metal, cultural politics in Singapore and Malaysia. Inter-Asia Cultural Studies 7(1): 99-112. https://doi. org/10.1080/14649370500463182

Maeda, N. 1975. Family circle, community, and nation in Malaysia. Current Anthropology 16(1): 163-166. https://doi.org/10.1086/201527

Minichiello, V., R. Aroni, E. Timewell and L. Alexander. 1995. In-depth interviewing: Researching people. Melbourne: Longman Cheshire.

Offord, B. 2003. Homosexual rights as human rights: Activism in Indonesia, Singapore, and Australia. Oxford: Peter Lang.

Peletz, M.G. 2009. Gender pluralism: Southeast Asia since early modern times. New York: Routledge. https://doi.org/10.4324/9780203880043

1996. Reason and passion: Representations of gender in a Malay society. Berkeley: University of California Press. 
Raybeck, D. 1986. The elastic rule: Conormity and deviance in Kelantan village life. In Cultural identity in northern Peninsular Malaysia, eds. S.A. Carstens, 55-74. Athens: Ohio University Center for International Studies.

Rousseau, J.-J. 1997. The social contract. In Rousseau: The social contract and other later political writings, translated by V. Gourevitch. New York: Cambridge University Press.

Scott, J.C. 1976. The moral economy of the peasant: Rebellion and subsistence in Southeast Asia. New Haven and London: Yale University Press.

Shamsul Amri Baharuddin. 2001a. A history of an identity, an identity of a history: The idea and practice of "Malayness" in Malaysia reconsidered. Journal of Southeast Asian Studies 32(3): 355-366.

2001b. "Malay" and "Malayness" in Malaysia reconsidered: A critical review. Communal/Plural: Journal of Transnational \& Crosscultural Studies 9(1): 6980 .

Shamsul Amri Baharuddin and Mohamad Fauzi Sukimi. 2006. Making sense of Malay sexuality: An exploration. SARI: Jurnal Alam dan Tamadun Melayu 24: 59-72.

Swift, M.G. 1965. Malay peasant society in Jelebu. New York: The Athlone Press.

Tan, B.H. 2012. Sexuality, Islam and politics in Malaysia: A study of the shifting strategies of regulation. PhD diss., Department of Southeast Asian Studies, National University of Singapore.

The Sun Daily. 2010. Engineer unfazed by anti-gay criticism, death threats. 26 December. http://www.thesundaily.my/node/134769 (accessed 27 December 2010).

Wazir, J.K. 1992. Women and culture: Between Malay adat and Islam. Boulder: Westview Press.

Winzler, R. 1990. Amok: Historical, psychological, and cultural perspectives. In Emotions of culture: A Malay perspective, eds. Wazir J.K., 96-122. Singapore: Oxford University Press.

Wong, Y. 2013. Queer travels: Networked society, digitizing queerness and political surveillance. AoIR Selected Papers of Internet Research. https://spir.aoir.org/ index.php/spir/article/view/856 (accessed 7 November 2017).

Zawawi Ibrahim. 1998. The Malay labourer: By the window of capitalism. Singapore: Institute of Southeast Asian Studies. 